\title{
Action Mechanism and Immunity Status of Broiler Chickens after Spray and Drinking Water Administration of Kanne-Brottrunk ${ }^{\circledR}$
}

\author{
Raheel I.A. ${ }^{1}$, Orabi A. ${ }^{2, *}$, Saber El-Hanbaly ${ }^{3}$, Hassan Shaheen ${ }^{4}$ \\ ${ }^{1}$ Department of Bacteriology, Mycology and Immunology, Faculty of Veterinary Medicine, Beni-Suief University, Egypt \\ ${ }^{2}$ Department of Microbiology, Faculty of Veterinary Medicine, Cairo University, Egypt \\ ${ }^{3}$ Department of Pharmacology, Faculty of Veterinary Medicine, Benha University, Egypt \\ ${ }^{4}$ Veterinarian in Egyptian Livestock Production Field \\ *Corresponding author: drorabi2012@yahoo.com, orabi.vet@cu.edu.eg
}

Received August 08, 2018; Revised September 17, 2018; Accepted October 08, 2018

\begin{abstract}
Poultry producers are challenged to improve production while using fewer antibiotics due to increased restriction on antimicrobial usage so prebiotics and probiotics are being tested under different experimental conditions to study the pathways used by these substances to assist in the prevention of carcass contamination and in the elimination of pathogens present in the bird's organisms. The current study aimed to investigate the effect of spray and orally administered Kanne-Brottrunk ${ }^{\circledR}$ which contain Lactobacillus and Bifidobacterium at which lactic acids bacteria concentration is $5 \times 10^{6} \mathrm{cfu} / \mathrm{ml}$ in addition to vitamins, minerals, essential amino acids and trace elements on the mucosal trachea IgA, IL-6 and INF- $\gamma$ as well as healthiness of intestinal and tracheal mucosa using electron microscopy. Six hundred one day old Cobb broilers chickens were reared on litter in three separated groups each one contain 200 chicks, $1^{\text {st }}$ group "Drinking Water Administrated", $2^{\text {nd }}$ group "Spray Administrated" and "control non Kanne-Brottrunk ${ }^{\circledR}$ medicated group". Serum, trachea and intestine collected for evaluation of immune status and epithelium healthiness at 14, 21, 28 and 35 day old. Immunological Parameters measured were IL-6, INF- $\gamma$ and Mucosal IgA concentration using EISA kits accompanied by tracheal and intestinal electron microscopy histomorphology. The results proved that Kanne-Brottrunk ${ }^{\circledR}$ administrated in water stimulate immune response by increased level of IL-6, INF- $\gamma$ and Mucosal IgA and also increase immune cells infiltration as plasma cell, lymphoid cells, macrophages, and heterophile in trachea and intestine with protection of their tracheal cilia and intestinal villi more than aerosol administration.
\end{abstract}

Keywords: Kanne-Brottrunk ${ }^{\circledR}, I L-6, I N F-\gamma$, Mucosal IgA, electron microscope

Cite This Article: Raheel I.A., Orabi A., Saber El-Hanbaly, and Hassan Shaheen, "Action Mechanism and Immunity Status of Broiler Chickens after Spray and Drinking Water Administration of Kanne-Brottrunk®." Journal of Applied \& Environmental Microbiology, vol. 6, no. 3 (2018): 59-66. doi: 10.12691/jaem-6-3-1.

\section{Introduction}

Sub-therapeutic use of antibiotics as growth promoters in animal feed has evoked wide spread concern, with their use banned in many countries due to the potential to develop antibiotic resistance in microbial populations associated with human and animal diseases. Probiotics are becoming one of the alternative to antibiotic growth promoters (AGP). The most important objectives of using probiotics are maintain and improve animal performance and prevent and control enteric pathogens. Probiotics are live microorganism when administered in adequate amount confer a health benefit on the host [1]. There are several types of probiotics available to be used in poultry, with arrange of microorganism present with different metabolic activities and actions. They present variations as to the capacity of colonizing the intestine or not, which justifies variations on the results of their use. The bacterial contents of the animal intestine contain over 400 bacterial species; $99 \%$ of these species are obligatory anaerobic and about $10 \%$ are Lactobacilli and Bifidobacteria [2]. Lactobacilli have the longest history as probiotics and are still among the most common ingredients used in animal feed. In chickens the passage of feed and other ingested material though GI-tract is relatively fast and this is important when using lactobacilli with probiotic characteristics, because of this short passage time probiotics in chickens have a very short time to exert their actions and therefore good adhesion or even colonization characteristic play an important role. Lactobacillus and Bifidobacterium are probably the safest microorganisms used as probiotics. Microorganisms used as probiotics are selected on the bases of their survival in the gastrointestinal environment and ability to withstand low $\mathrm{PH}$ and high concentration of bile acids and another desirable characteristic is the ability to adhere to the 
intestinal epithelium [3]. This work was planned to investigate the effect of spray and orally administered Kanne-Brottrunk ${ }^{\circledR}$ which contain Lactobacillus and Bifidobacterium which are still alive in the gut as they are resistant against the gastric acid and digestive enzymes, lactic acids bacteria concentration is $5 \times 10^{6} \mathrm{cfu} / \mathrm{ml}$ in addition to vitamins, minerals, essential amino acids and trace elements on the mucosal trachea IgA, humoral immune response, cellular immune response as well as healthiness of cilia of upper respiratory tract and intestinal mucosa using electron microscopy.

\section{Materials and Methods}

\subsection{Chickens}

Six hundred one day old Cobb broilers chickens were reared on litter in three separated groups, balanced rations and clean drinking water were given continuously, the following vaccination program was applied ;Hitcher B1 at 6 day of age, IBD "intermediate plus strain" at 13 days of age and Lasota strain at 18 day of age. Anti-mycoplasma drug (Tilmycosin phosphate, $275 \mathrm{mg}$ ) was given in the first 3 days for 8 hours daily.

\subsection{Experimental Design}

$\mathbf{1}^{\text {st }}$ group "Drinking Water Administrated: Comprising 200 chicks; Kanne-Brottrunk ${ }^{\circledR}$ was given orally according to the producer recommended dose as follow (Table 1).

Table 1. Kanne-Brottrunk ${ }^{\circledR}$ drinking water dosage

\begin{tabular}{c|c|c|c}
\hline Age (week) & Days & $\begin{array}{c}\text { Daily dosage/1000 } \\
\text { chicks }\end{array}$ & $\begin{array}{c}\text { Days of } \\
\text { administration }\end{array}$ \\
\hline 1 & $0-7$ & $55 \mathrm{ml}$ & $4 ; 5 ; 6 ; 7$ \\
\hline 2 & $8-14$ & $65 \mathrm{ml}$ & $11 ; 12 ; 13 ; 14$ \\
\hline 3 & $15-21$ & $90 \mathrm{ml}$ & $18 ; 19 ; 20 ; 21$ \\
\hline 4 & $22-28$ & $120 \mathrm{ml}$ & $25 ; 26 ; 27 ; 28$ \\
\hline
\end{tabular}

$2^{\text {nd }}$ group "Spray Water Administrated":

Comprising 200 chicks; Kanne-Brottrunk ${ }^{\circledR}$ was sprayed according to the producer recommended dose as follow (Table 2)

Table 2. Kanne-Brottrunk ${ }^{\circledR}$ drinking water dosage

\begin{tabular}{c|c|c|c}
\hline $\begin{array}{c}\text { Age } \\
\text { (week) }\end{array}$ & Days & $\begin{array}{c}\text { Daily dosage/1000 } \\
\text { chicks }\end{array}$ & $\begin{array}{c}\text { Days of } \\
\text { administration }\end{array}$ \\
\hline 1 & $0-7$ & $55 \mathrm{ml} / 250 \mathrm{ml}$ water & $4 ; 5 ; 6 ; 7$ \\
\hline 2 & $8-14$ & $65 \mathrm{ml} / 350 \mathrm{ml}$ water & $11 ; 12 ; 13 ; 14$ \\
\hline 3 & $15-21$ & $90 \mathrm{ml} / 500 \mathrm{ml}$ water & $18 ; 19 ; 20 ; 21$ \\
\hline 4 & $22-28$ & $120 \mathrm{ml} / 600 \mathrm{ml}$ water & $25 ; 26 ; 27 ; 28$ \\
\hline
\end{tabular}

$3^{\text {rd }}$ group "Control non Kanne-Brottrunk ${ }^{\circledR}$ medicated group": Comprising 200 chicks; non Kanne-Brottrunk ${ }^{\circledR}$ medicated

\subsection{Samples}

a. Serum: collected at 14, 21, 28 and 35 days of age from all groups for determination interleukins-6 and interferon gamma concentration b. Trachea: collected at 14, 21, 28 and 35 days of age from all groups for determination mucosal IgA conc. also morphological study using Electron Microscope.

c. Intestine: collected at 14, 21, 28 and 35 days of age from all groups for histomorphological study using Electron Microscope.

\subsection{Immunological Parameters}

a. Interleukin-6 (IL-6 conc.). Was determined using Sandwich-ELISA (Novatein Bio, Massachusetts, USA) [4].

b. Interferon-gamma (INF- $\boldsymbol{\gamma}$ ) assay. Was determined by immunoenzymatic assay. Chicken INF- $\gamma$ ELISA kits (Novatein Bio, Massachusetts, USA) according to [5].

c. Mucosal IgA conc. The concentrations of immunoglobulins A in the trachea was measured using commercial ELISA kit for chickens (Catalog No. E30-103, Bethyl Laboratories Inc., Montgomery, TX 77356) according to [6]

\subsection{Statistical Analysis}

The results were presented as means \pm SE. All given parameters were compared between the control group and the experimental groups using the one way ANOVA with fixed effects of the factors using statistica 6.0 (Start Soft INC.). Differences were considered significant at $\mathrm{p}<0.05$.

\subsection{Histomorphology}

Trachea and intestine were admitted to Electron Microscope unit, Assiut University for Histomorphological study according to [7].

\subsection{Performance Parameters}

a. Feed intake and feed efficiency according to [8].

b. Body weight gain according to [9].

\section{Results}

\subsection{Results of Immunological Parameters (For Details See Table 3)}

a. Results of IL6 conc.: IL6 conc. in $1^{\text {st }}$ group ranged from $21,26,30$ and $35 \mathrm{pg} / \mathrm{ml}$, while $2^{\text {nd }}$ group recorded the following results 19,24,27 and $28 \mathrm{pg} / \mathrm{ml}$ and $3^{\text {rd }}$ group results were $10,12,14$ and $16 \mathrm{pg} / \mathrm{ml}$ at $14,21,28$ and 35 days of age respectively.

b. Results of IFN- $\gamma$ conc.: IFN- $\gamma$ conc. in $1^{\text {st }}$ group ranged from 196,344,494 and $510 \mathrm{pg} / \mathrm{ml}$, while $2^{\text {nd }}$ group recorded the following results $180,318,436$ and $492 \mathrm{pg} / \mathrm{ml}$ and $3^{\text {rd }}$ group results were 75,75,85 and $120 \mathrm{pg} / \mathrm{ml}$ at $14,21,28$ and 35 days of age respectively.

c. Results of tracheal IgA conc.: mucosal IgA conc. in $1^{\text {st }}$ group ranged from 14,39,110 and $192 \mathrm{pg} / \mathrm{ml}$, while $2^{\text {nd }}$ group recorded the following results $24,54,116$ and $242 \mathrm{pg} / \mathrm{ml}$ and $3^{\text {rd }}$ group results were $10,18,45$ and $90 \mathrm{pg} / \mathrm{ml}$ at 14,21,28 and 35 days of age respectively. 
Table 3. Results immunological parameters

\begin{tabular}{|c|c|c|c|c|c|c|c|c|c|}
\hline \multirow[t]{2}{*}{ Age } & \multicolumn{3}{|c|}{$\begin{array}{l}\text { ELISA Il6 Conc. "pg } \backslash \text { ml" } \\
\text { (Mean } \pm \text { SD) }\end{array}$} & \multicolumn{3}{|c|}{$\begin{array}{c}\text { ELISA IFN-gamma Conc. "pg } \backslash \mathrm{ml} " \\
\text { (Mean } \pm \text { SD) }\end{array}$} & \multicolumn{3}{|c|}{$\begin{array}{l}\text { ELISA IgA conc. "ng } \backslash \mathrm{ml} " \\
(\text { Mean } \pm \text { SD) }\end{array}$} \\
\hline & $1^{\text {st }}$ gp & $2^{\text {nd }} g p$ & $3^{\text {rd }}$ gp & $1^{\text {st }}$ gp & $2^{\text {nd }} g p$ & $3^{\text {rd }}$ gp & $1^{\text {st }}$ gp & $2^{\text {nd }} g p$ & $3^{\text {rd }} \mathrm{gp}$ \\
\hline $14 \mathrm{~d}$ & $21 \pm 0.1$ & $19 \pm 0.2$ & $10 \pm 0.4$ & $196 \pm 0.285$ & $180 \pm 0.233$ & $75 \pm 0.434$ & $14 \pm 0.124$ & $24 \pm 0.132$ & $10 \pm 0.232$ \\
\hline $21 \mathrm{~d}$ & $26 \pm 0.1$ & $24 \pm 0.2$ & $12 \pm 0.2$ & $344 \pm 0.455$ & $318 \pm 0.633$ & $75 \pm 0.530$ & $39 \pm 0.128$ & $54 \pm 0.138$ & $18 \pm 0.322$ \\
\hline $28 \mathrm{~d}$ & $30 \pm 0.3$ & $27 \pm 0.2$ & $14 \pm 0.2$ & $494 \pm 0.633$ & $436 \pm 0.380$ & $85 \pm 0.350$ & $110 \pm 0.125$ & $116 \pm 0.152$ & $45 \pm 0.320$ \\
\hline $35 \mathrm{~d}$ & $35 \pm 0.4$ & $28 \pm 0.3$ & $16 \pm 0.3$ & $510 \pm 0.250$ & $492 \pm 0.253$ & $120 \pm 0.250$ & $192 \pm 0.165$ & $242 \pm 0.175$ & $90 \pm 0.155$ \\
\hline
\end{tabular}

Figs (A): Results of electron microscopy for $\left(1^{\text {st }} \mathrm{gp}\right.$ oral administration) 14 day old broiler chickens

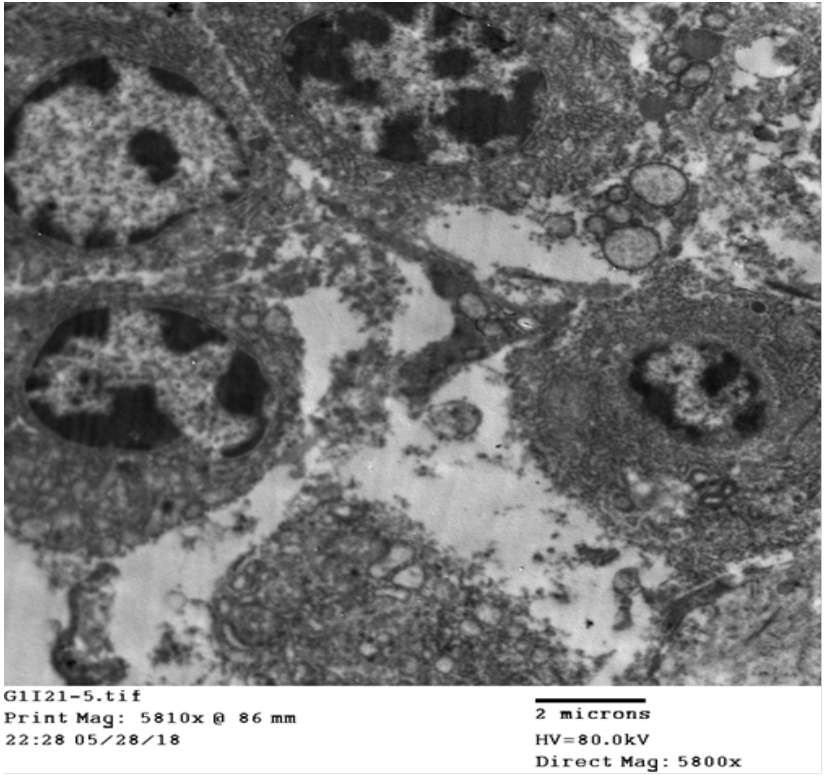

Figure 1. Micrograph of intestinal villi showing the villous core infiltrated with lymphoid and macrophage cells. Also presence of endocrine cell contain electron dens granules embedded in between the epithelia cells

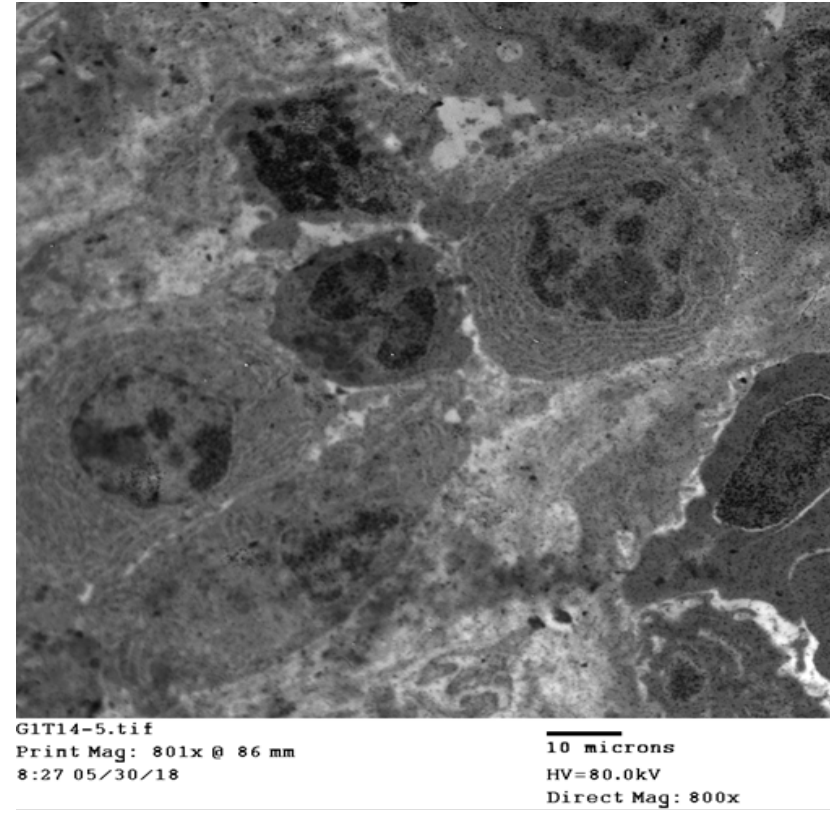

Figure 2. Micrograph of trachea sub epithelial lamina showing blood capillary edema and cellular infiltration in form of plasma cell, lymphoid cell, heterophile and macrophage

\section{1 day old broiler chickens}

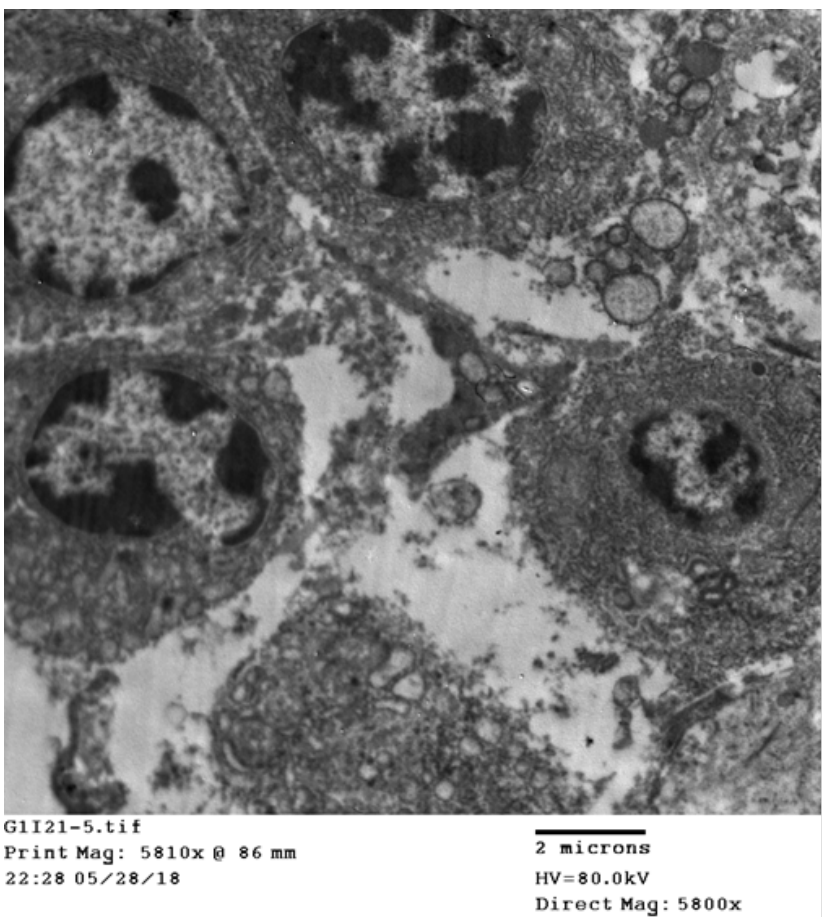

Figure 3. Micrograph of the villous core of the villi contains numerous plasma cells and macrophage with milled edema

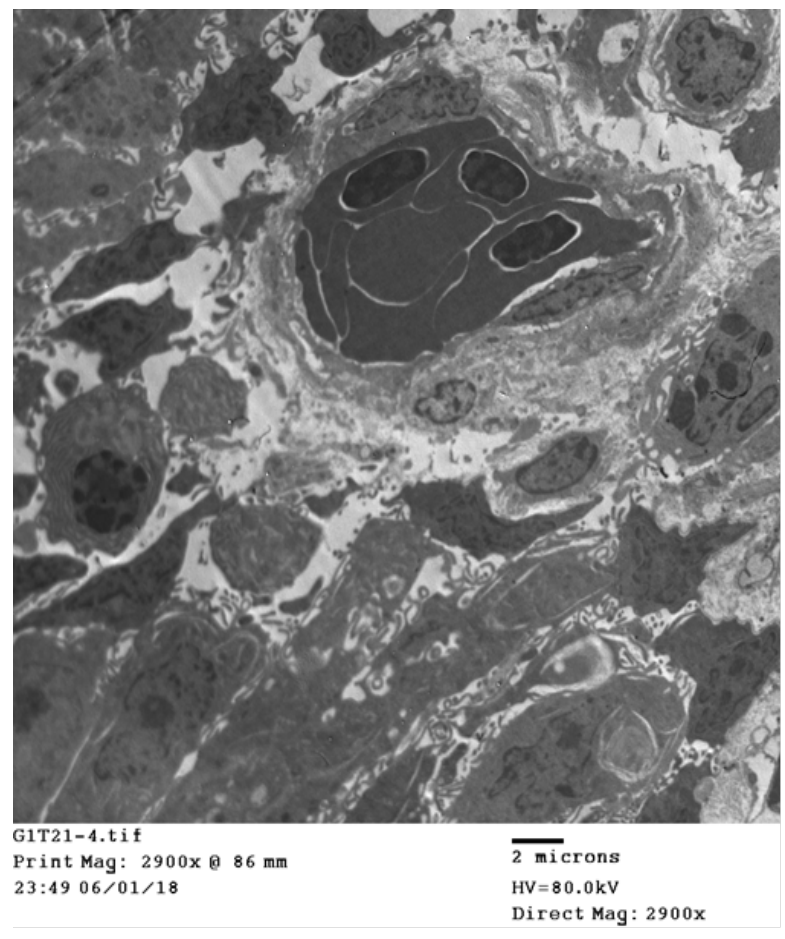

Figure 4. Micrograph of trachea sub epithelial showed congestion of the vasculature, edema and presence of plasma and macrophage cells 


\subsection{Results of Histomorphology}

As showed in Figs (A, 1, 2, 3, 4, 5, 6, 7 and 8) for drinking water treated group there was an increase in immune cells infiltration and epithelium healthiness of intestinal villi, while Figs (B, 9, 10, 11, 12, 13, 14, 15, and 16) for aerosol treated group, there were dramatic stimulation of mucosal immune cells in both trachea

\section{8 day old broiler chickens}

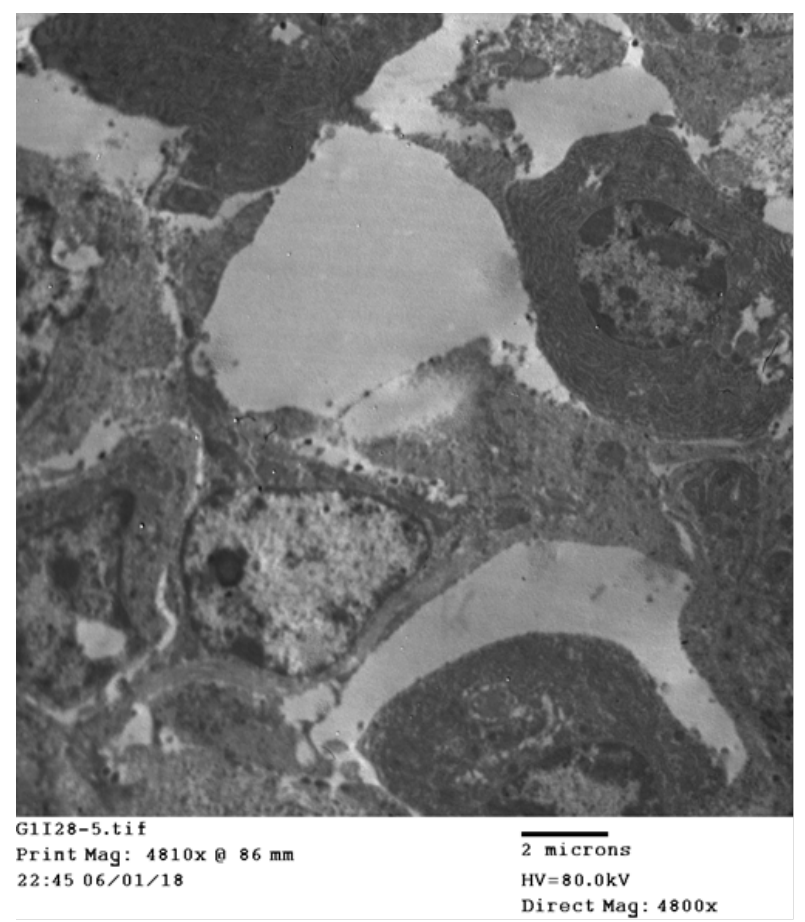

Figure 5. Micrograph of the villous core contain numerous plasma cells, lymphocytes and macrophages with inter cellular edema and intestine with increase in proliferation of plasma cells, macrophages, lymphoid cells, endocrine cells, goblet cell and heterophiles. At the same time, aerosol treated group (G2-Tr-21,28 and 35 days of age) showed deciliation of moderate areas of the covering epithelium with rupture of goblet cells on the surface sometimes with swelling of the surface epithelium especially when compared with normal trachea at 21 day old chickens (Figure 12b).

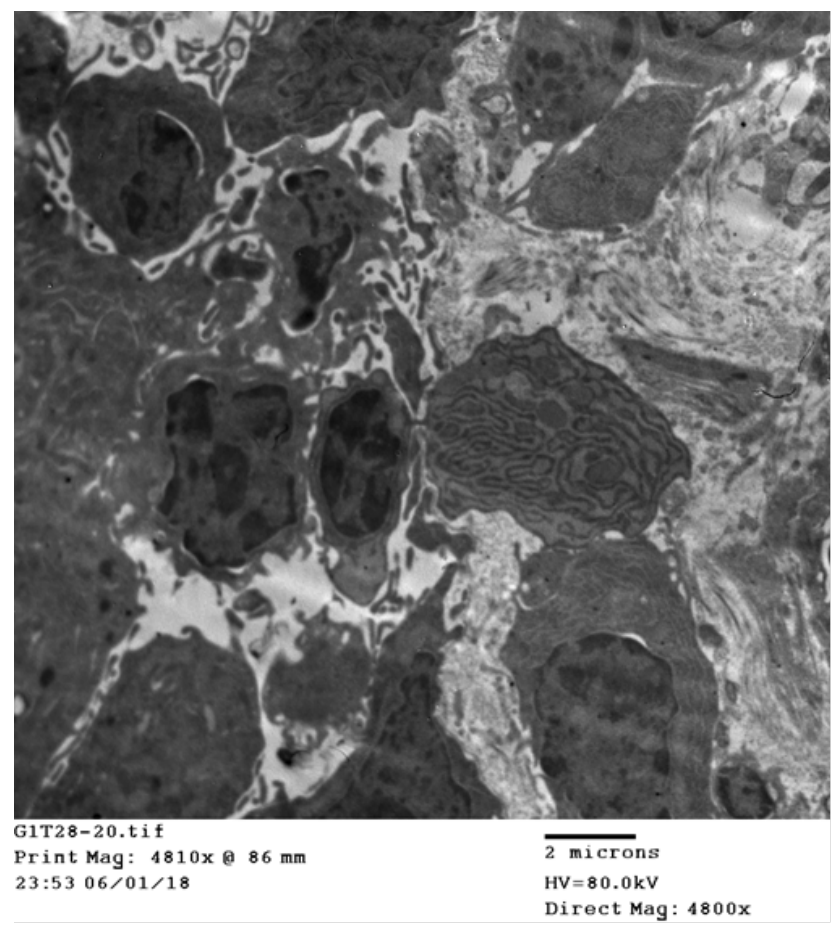

Figure 6. Micrograph of the trachea showing the sub epithelial connective tissue contains few plasma, lymphocytes and macrophages

\section{5 day old broiler chickens}

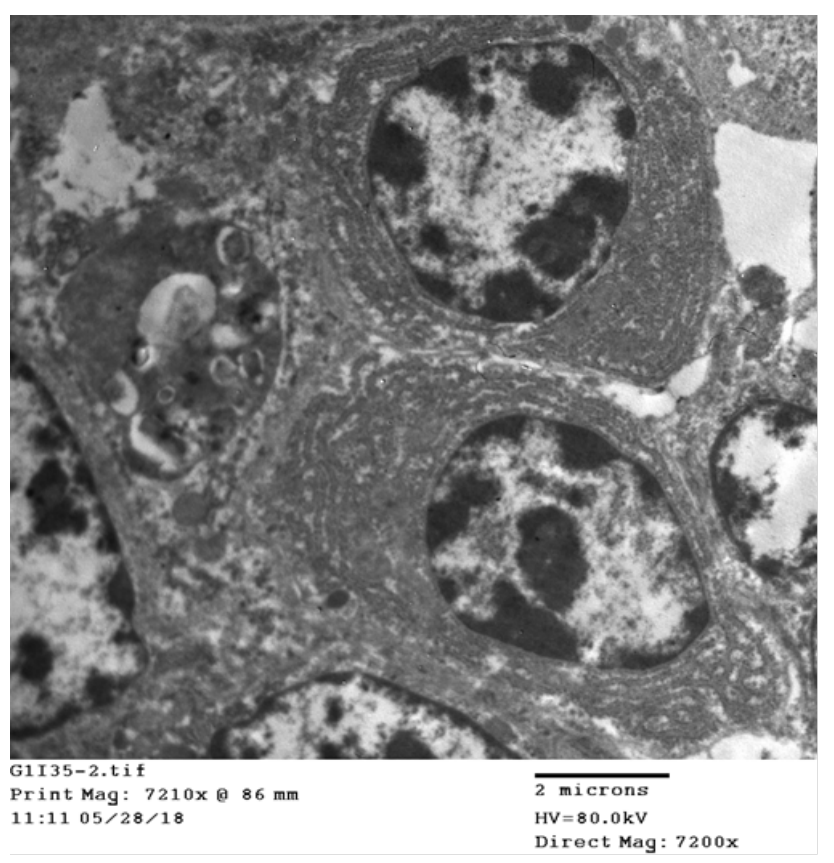

Figure 7. Micrograph of the villous core showing presence of numerous plasma cells, lymphocytes and macrophages

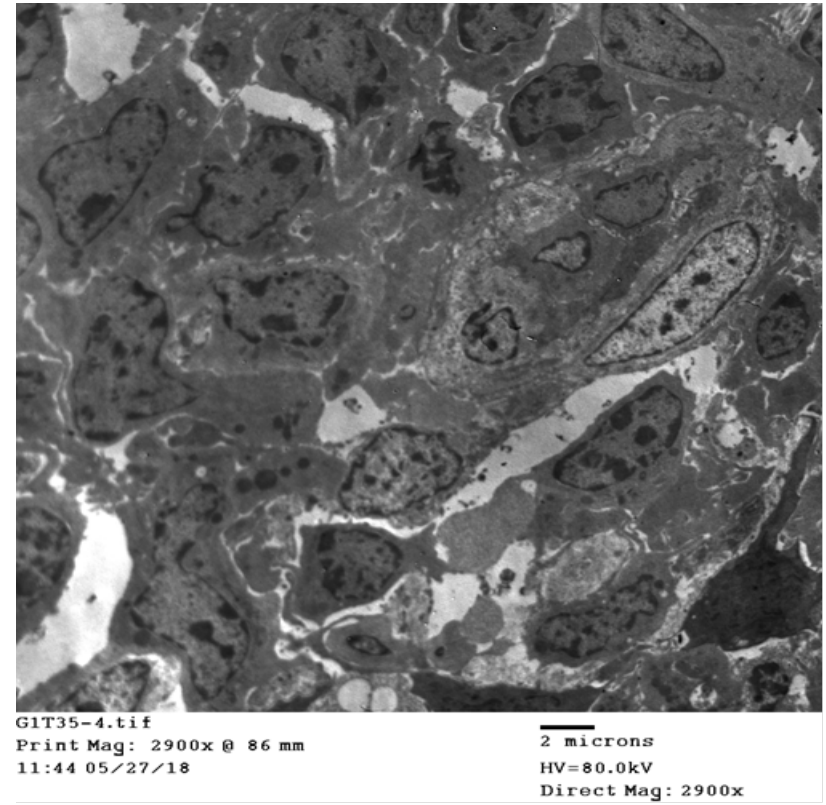

Figure 8. Micrograph of trachea sub epithelial lamina of the trachea showing cellular infiltration of lymphoid and macrophages with edema in between 
Figure (B): Results of electron microscopy for $\left(2^{\text {nd }} \mathrm{gp}\right.$ Spray administration) 14 day old broiler chickens

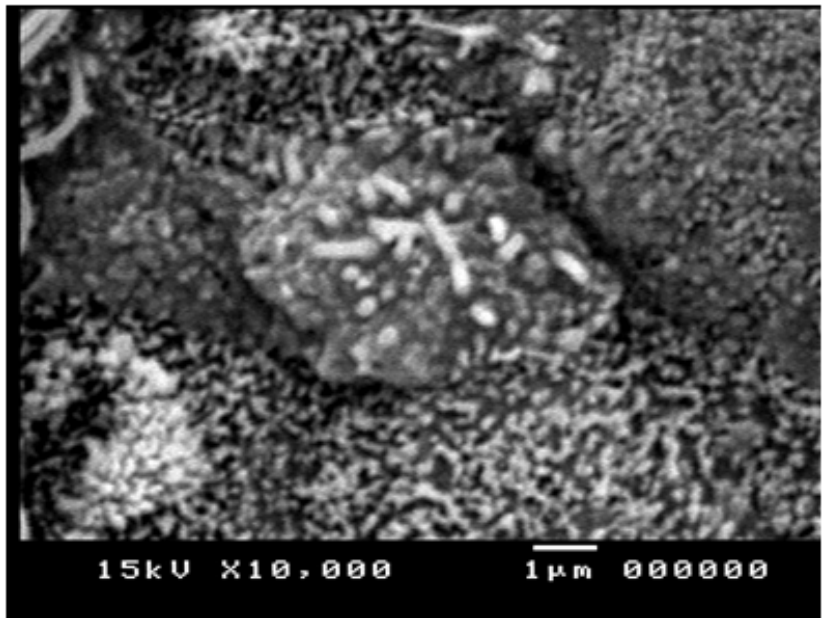

Figure 9. Micrograph of the epithelial covering the trachea showing presence of large number of bacterial organism in the upper portion of the cells. Also presence of goblet cell contain mucous

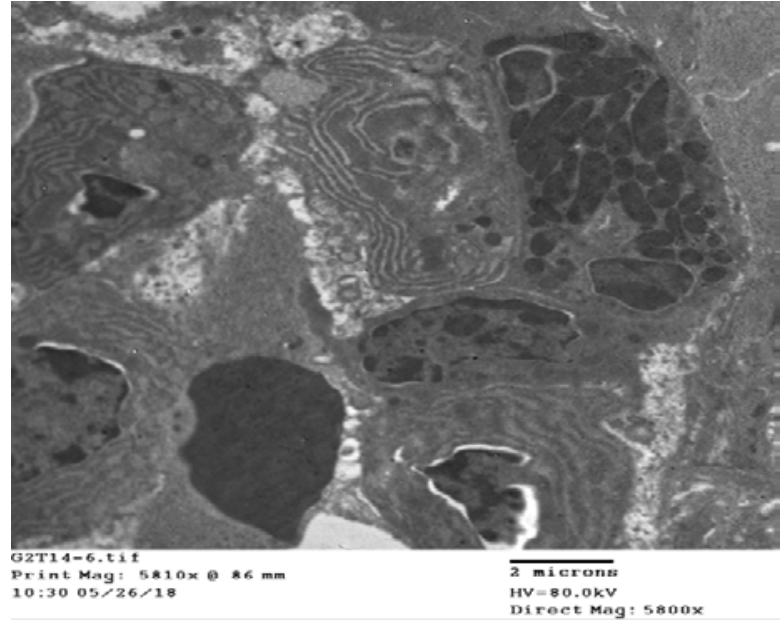

Figure 10. Micrograph of trachea sub epithelia connective tissue of the trachea showing presence plasma cell, lymphoid cells and heterophile cell contain bacillus organism

\section{1 day old broiler chickens}

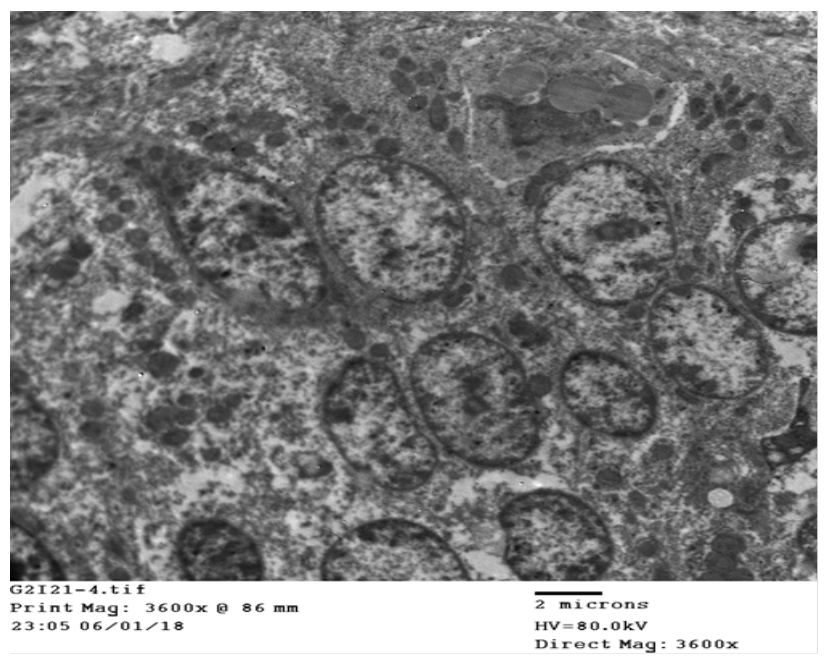

Figure 11. Micrograph of intestinal covering epithelium of the villous showing hyperplasia Also presence of numerous phagocytic cells containing bacillus bacterial organism similar to that observed in the tracheal epithelium

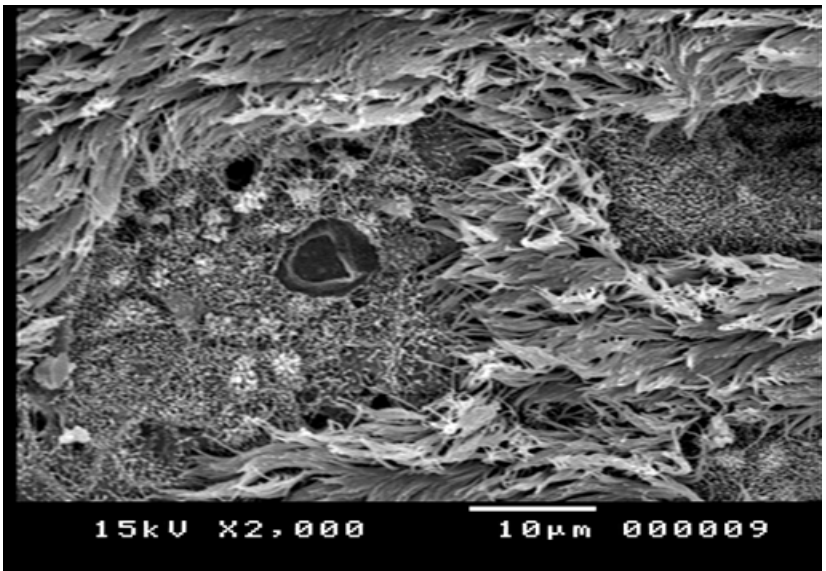

Figure 12a. Micrograph of the tracheal surface showing decilliation of moderate areas of the covering epithelium with rupture of goblet cell on the surface

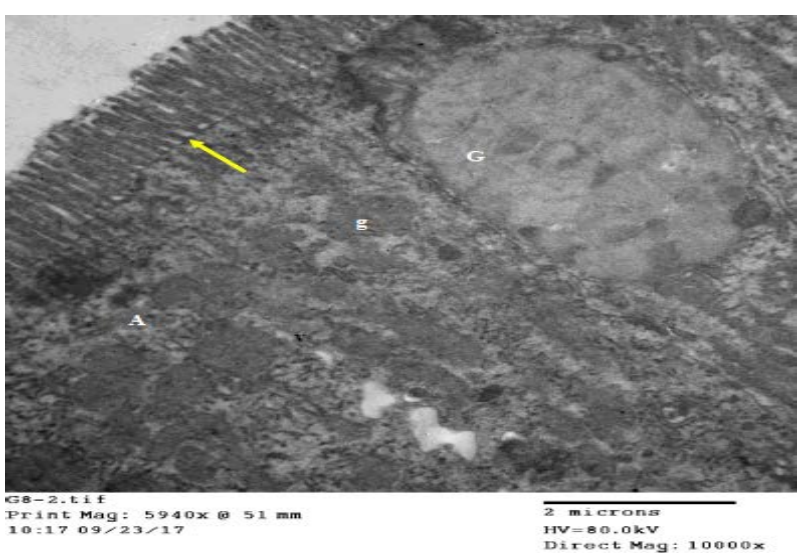

Figure 12b. Micrograph showing the absorptive cells having cilia (arrow) about 1 micron length. The cytoplasm contain mitochondria, free ribosomes, RER, absorptive vacuoles and electron dens granules The goblet cell destined with mucus globule and found embedded in between the absorptive cells.(normal tracheal cilia at 21 day old chickens) 
28 day old broiler chickens

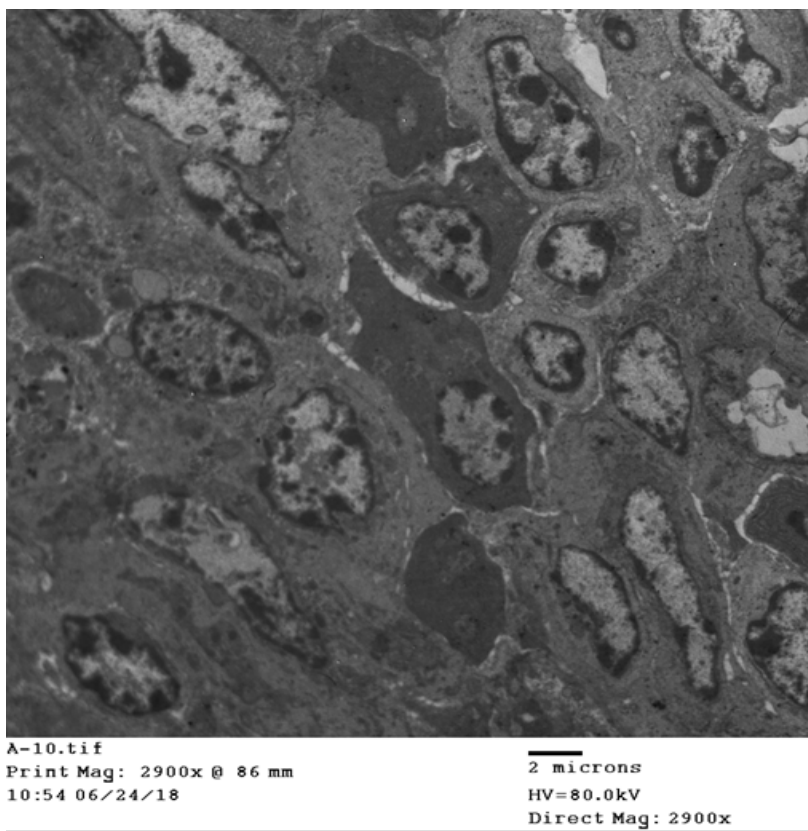

Figure 13. Micrograph of the villous core of the villous showing presence of plasma cells, lymphocytes and macrophages (4)

\section{5 day old broiler chickens}

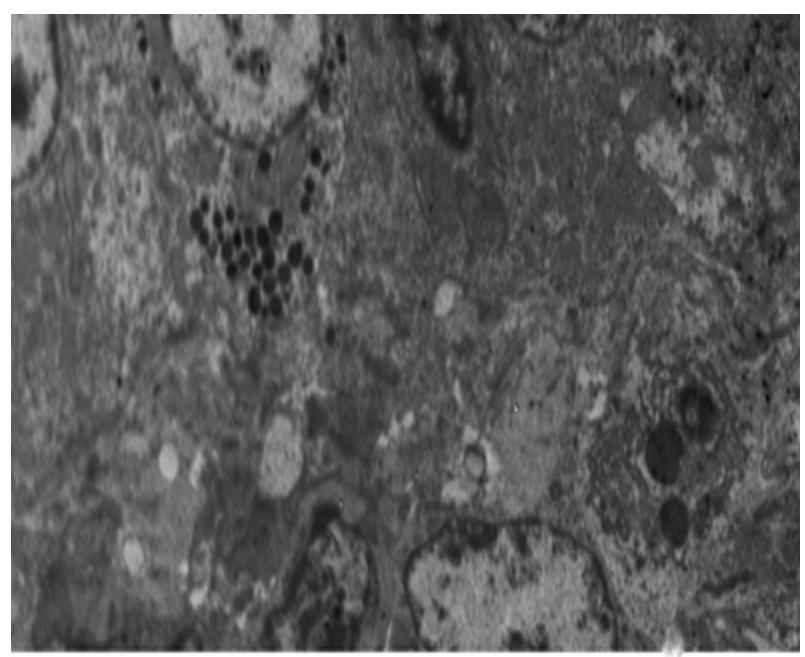

\section{A-11.tif}

Print Mag: 3600x $086 \mathrm{~mm}$

$11: 1706 / 24 / 18$

\section{2 microns}

$\mathrm{HV}=80.0 \mathrm{kV}$

Direct Mag: 3600x

Figure 15. Micrograph of the villous showing the epithelial cells hyperplasic and presence of endocrine cells contain electron dens granules. Also presence of immune cells

\section{Results of Performance Parameters}

Feed intake and feed efficiency: feed intake in in $1^{\text {st }}$ group was $680 \mathrm{~kg}$, while in $2^{\text {nd }}$ group $690 \mathrm{~kg}$ and 702 in control group. While Body weight gain: mean body weight of the control group was $1.950 \mathrm{~kg}$ (1.8 FCR), while in $1^{\text {st }}$ group was $2.100 \mathrm{~kg}(1.6 \mathrm{FCR})$ and $2 \mathrm{~kg}$ for $2^{\text {nd }}$ group (1.7 FCR).

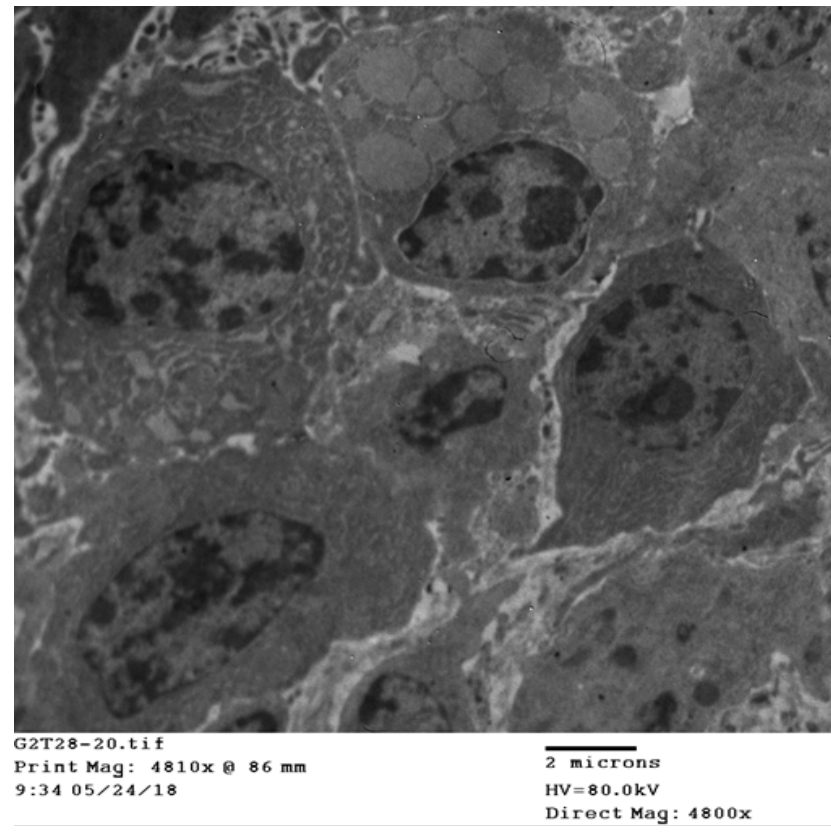

Figure 14. Micrograph of trachea lamina propria of the sub epithelium showing infiltrated by plasma cells, lymphoid cell and macrophages

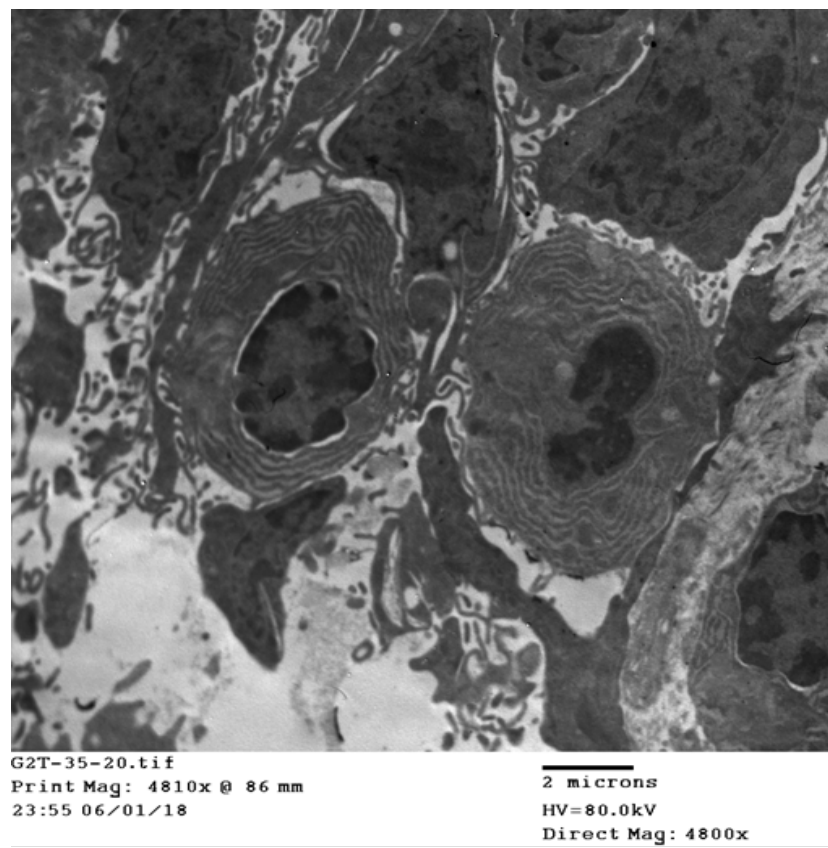

Figure 16. Micrograph of the tracheal showing presence of numerous plasma cells in the sub- epithelium with edema

\section{Discussion}

A prebiotic is a non-digestible food ingredient that beneficially affects the host by selectively stimulating the growth and/or activity of normal flora. Among the most commonly studied substances in the family of prebiotics are the oligosaccharides, which are non-digestible carbohydrates, particularly fructo-ligosaccharides (FOS), 
gluc-oligosaccharides (GOS), and mannano-ligosaccharides (MOS) [10]. Prebiotics may change gut microbiota in two ways: (i) by supplying the nutrients for beneficial bacteria, or (ii) by leading pathogenic bacteria to acknowledge attachment sites in oligosaccharides as intestinal mucosa sites, thus reducing undesired intestinal colonization, which in turn decreases the incidence of infections and improves the integrity of the mucosal surface of the gut wall [11]. On the other hand, the mode of action of probiotics is related to the competition for attachment sites, or competitive exclusion. The bacteria present in the probiotic attach to the intestinal mucosa, thus forming a physical barrier that blocks the attachment of pathogenic bacteria [12].

In chicken, the passage of feed and other ingested materials through GIT is relatively fast 2-5 hours [13], this is not only importance for the digestion and absorption but it is also of importance with respect to the administration of Lactobacilli with probiotic characteristic therefore good adhesion or even colonization characteristics play an important role. According to [14] and [15], The bacterium genera present in probiotics that are directly related to the increase in immunity of poultry are Lactobacillus and Bifidobacterium mainly when related to diseases affecting the gastrointestinal tract, while according to $[16,17]$. The antigens (Lipopolysaccharides and Peptidoglycans) are constantly released in intestinal lumen and are fundamental in the development and maintenance of local immune response since they have chemotactic effect on epithelial cells and cells related to mucosa immunity and induce changes in intestinal epithelium of the host. The mean IL6 concentration in orally administrated group ( $1^{\text {st }} \mathrm{Gp}$ ) were $21,26,30$ and 35 $\mathrm{pg} / \mathrm{ml}$ compared with 19,24,27 and $28 \mathrm{pg} / \mathrm{ml}$ in sprayed group $\left(2^{\text {nd }} G\right.$ p) in sera collected at $14,21,28$ and 35 days respectively, compared with 10,12,14,16 pg/ml in control ( $\left.3^{\text {rd }} \mathrm{gp}\right)$. Concerning IFN- $\gamma$ mean concentration in orally and spray treated groups, the following concentration were recorded 196,344,494 and $510 \mathrm{pg} / \mathrm{ml}$ in (Gp1) and 180,318,436 and $492 \mathrm{pg} / \mathrm{ml}$ in (Gp2) at 14,21,28 and 35 days respectively, compared with $75,75,85,120 \mathrm{pg} / \mathrm{ml}$ in control group. GIT component of the immune system protecting the host from different types of antigens in the lumen of the GIT is affected by probiotics. Both innate and adaptive immunity are affected by probiotics. Probiotics formulations prevent chronic inflammation of the GIT through stimulation of innate immunity $[18,19]$. Several studies have demonstrated immunostimulatory effects of probiotics. Bai et al., [3] demonstrated that a probiotic containing L.fermentum and S.cervisae stimulated intestinal T-cell immune system, indicated by increased production of $\mathrm{CD} 3+$, CD4+ and CD8+ T-lymphocytes in the GIT broiler chickens. Expression of CD3+, IL2 and IFN- $\gamma$ genes was significantly greater in the small intestine of neonatal chicks (day 3 and 7) fed with Lactobacillus spp. [20]. Concerning results of mucosal IgA concentrations in Gp1 which recorded 14,39,110 and $192 \mathrm{ng} / \mathrm{ml}$ compared with 24, 54,116 and $242 \mathrm{ng} / \mathrm{ml}$ in Gp2 at 14, 21, 28 and 35 days respectively, also control group values were $10,18,45$ and $90 \mathrm{ng} / \mathrm{ml}$ Probiotics increase serum immunoglobulins levels [21], studied the effects of probiotics on serum level of IgA and
IgM in chickens and recorded a significant increased levels, also Landy and Kavyani [8]., noticed increase in antibody against the common poultry diseases Newcastle, infectious bronchitis and infectious bursal disease after treatment with probiotics.

Probiotics maintain the proper balance of useful microbial population in the intestine of bird, which is important for the efficient feed conversion, growth, productivity and stimulation of birds' immune mechanisms to combat pathogens [22]. It has been proved that effective probiotics help to accelerate development of normal micro flora in chicks and poults (Bansal, et al., 2011). Even spray applications of probiotic have been found to be effective against Salmonella infection in chicks [23]. As feed additive, probiotics show a good impact on the poultry performance [24]. Establishing and maintaining healthy gut microflora is essential, which improves the microbial environment of a bird's intestinal tract by displacing harmful bacteria. Especially, in newly hatched chicks, the gut is sterile and starts acquiring microflora from environment. Since pathogenic microbes may multiply faster than the beneficial bacteria, chicks may get infected at this time. Successful colonization of probiotics depends on the survival and stability of the microbial strain used, their relationship with the host, dose and usage frequency, and host health, nutritional status, age, stress and genetics [25]. In the present study application of Kanne-Brottrunk ${ }^{\circledR}$ by aerosol method accompanied by dramatic stimulation of mucosal immune cells in both trachea and intestine which gather by increase proliferation of plasma cells, macrophages, lymphoid cells, endocrine cells, goblet cell and heterophiles. At the same time, aerosol treated group (G2-Tr-21, 28 and 35 days of age) showed deciliation of moderate areas of the covering epithelium with rupture of goblet cells on the surface sometimes with swelling of the surface epithelium.

\section{References}

[1] FAO/WHO. 2001. Health and nutritional properties of probiotics in food. Food and Agriculture Organization of the United Nations.

[2] Vanbelle M, Teller E, Focant M. 1990. Probiotics in animal nutrition: a review. Arch Tierernahr.40:543-567.

[3] Bai, S., Wu, A., Ding, X., Lei, Y., Bai, J., Zhang, K., and Chio, j. 2013. Effects of probiotics supplemented diets on growth performance and intestinal immune characteristics of broilers chickens. Poultry sci. 92(3):663-670.

[4] Kalyuzhny, A.E.2005. Chemistry and biology of ELISPOT assay. Methods. Mol. Biol (Clifton, Nj ). 302:15-31.

[5] Karakolev, R.; Gospodinova, K.; Sotirov, L.; Nikolov, D.; Angelov, A. and Koynarski, Ts.(2015): Blood serum interferonalpha and - gamma concentrations in broiler chickens treated with the immunomodulator Helpankar. Int. Curr. Microbiol. App. Sci., 4(10): 296-299.

[6] Guillermo Tellez, Rubén Merino Guzmán’ Juan David Latorre'Ramiro Delgado Xochitl Hernandez-Velasco, Amanda Desha Wolfenden, Kyle Dean Teague, Lucas Elzie Graham, Brittany Danielle Mahaffey, Mikayla Francis AnnBaxter Billy and, Marshall Hargis, 2017: Comparison of total immunoglobulin A levels in different samples in Leghorn and broiler chickens. Asian Pacific Journal of Tropical Biomedicine, Volume 7, Issue 2, February 2017, Pages 116-120.

[7] Bozzola. J. and Russell, L. 1991. Electron microseopy principles and techniques for biologists: Jones and Bartlitt publishers 20 park plasa Boston Ma o 2116. 
[8] Landy,N. and Kavyani,A.2013.Effects of using a multi-strain probiotic on performance,immune system and caecal microflora composition in broiler chickens reared under cyclic heat stress condition. Iranian journal of Applied Animal science. 3(4): 703-708.

[9] Abdel-Rhman, H., Shawky, S., Ouda, H., Nafeaa, A., Orabi, S.213. Effect of two probiotics and bioflavonoids supplementation to the broilers diet and drinking water on the growth performance and hepatic antioxidant parameters. Global Veterinaria. 10(6): 734-741.

[10] Gibson GR, Roberfroid MB. Dietary modulation of the human colonic microbiota: Introducing the concepts of prebiotics. Journal of Nutrition 1995; 125(6): 1401-1412.

[11] Iji PA, Tivey DR. Natural and synthetic oligossaccharides in broiler chickens diets. World's Poultry Science Journal 1998; 54: 129-143.

[12] Furlan RL. Avaliaçəo e uso de pré e probiticos. $6^{\circ}$ Simpśio Brasil Sul de Avicultura; 2005; Chapec, Santa Catarina. Brasil. p. 58-76.

[13] BuyseJ, Adelson DS, Decuypere E, Scanes GC.1993.Diurnalnocturnal changes in food intake,gut storage of ingesta,food transit time and metabolism in growing broilers chickens:a model for temporal control of energy balance.. Poultry sci.34:699-706.

[14] Erickson, K.L. and Hubbbard, N.E. (2000). Probiotics immunomodulation in health and diseases. The journals of Nutrition.Vol.130, No.2. Feb 2000. PP.403-409.

[15] Menten, J.F.M. and Loddi, M.M. 2003. Probioticos, prebioticos e aditivos fitogenicos na nutricao de aves. Proceedings of simposio de nurticao de aves e suinos, Campinas, Sao Paulo, PP. 107-138.

[16] Loddi, M.M. 2003. Probioticos, prebioticos e acidificants orgnicos em dietas para frangos de corte.52f. Tese (Doutorado em Zootecnia)-Fuculdade de Ciencias Agrarias e Veterinarias, Universidade Estadual Paulista "Julio de Mesquita Filho", Jaboticabal.
[17] Nunes, A.D. 2008. Influencia do uso de aditivos alternativos a antimicrobians sobre o desempenho,morfologia intestinal e immunidade de frangos de cote.111f. Dissertacao(Mestrado em Medicina Veterinaria), Faculadade de Medicina Veterinaria e Zootcnia, Universidade de Sao Paulo.

[18] Galdeano. C.M. and Perdigon, G. 2006. The probiotic bacterium Lactobacillus casei induce activation of the gut mucosal immune system through innate immunity. Clinical vaccine immunology. 13(2): 219-226.

[19] Pagnini, C., Saeed, R., Bamias, G., Arseneau, K.O., Pizarro, T.T., and Cominelli, F. 2010. Probiotics promote gut health through stimulation of epithelial innate immunity proceeding of the national academy science of the united state of America, 107(1): 454-459.

[20] Sato, K., Takahashi, K., Tohno, M., Miura, Y., Kamada, T., Ikegami, S. and Kitazawa, H. 2009. Immunomodulation in gut associated lymphoid tissue of neonatal chicks by immunobiotic diets.

[21] Zhang, Z. and Kim, I. 2014. Effects of multistrain probiotics on growth performance apparent ileal nutrient digestibility, blood characteristics, ceacal microbial shedding and excreta odor contents of broilers.. Poultry sci.92 (3):364-370.

[22] Dhama K and Singh S D. (2010). Probiotics improving poultry health and production: an overview. Poultry Punch, 26(3): 41.

[23] Wolfenden A D, Vicente J L, Higgins J P, Andreatti R, Higgins S E, Hargis B M and Tellez G. (2007). Effect of organic acids and probiotics on Salmonella Enteritidis infection in broiler chickens. Int. J. Poult. Sci., 6: 403-405.

[24] Hajati H and Rezaei M. (2010). The application of probiotics in poultry production. Inter. J. Poult. Sci., 9: 298- 304.

[25] Mason C K, Collins M A and Thompson K. (2005). Modified electroporation protocol for lactobacilli isolated from the chicken crop facilitates transformation and the use of genetic tool. J. Microbiol. Methods, 60:353-363. 